\title{
EVALUATION OF STANDARD DURABILITY TESTS TOWARDS THE QUALIFICATION PROCESS FOR THE GLASS-ZEOLITE CERAMIC WASTE FORM
}

Lin J. Simpson and David J. Wronkiewicz
Chemical Technology Division

$$
F \cdots \cdot 20198
$$

Argonne National Laboratory

9700 South Cass Avenue

Argonne, IL 60439-4837

The submitted manuscripl has been
authored by a contractor of the U.S.
Govemment under contract No. W-31-108-
ENG-38. Accordingly, the U.S. Government
retains a nonexclusive, royalty-free license
to publish or reproduce the published form of
this contribution, or allow others to do so, for
U.S. Government purposes.

Accepted for Publication

1996 Fall Meeting

Materials Research Society

Boston, MA

December 2-5, 1996
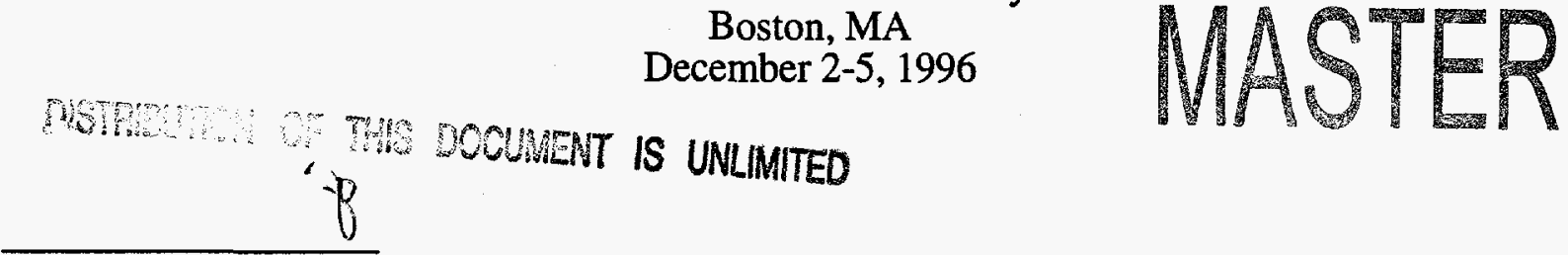

Work supported by the U.S. Department of Energy, Nuclear Energy Research and Development Program, under contract W-31-109-ENG-38.

\section{DISCLAIMER}

This report was prepared as an account of work sponsored by an agency of the United States Government. Neither the United States Government nor any agency thereof, nor any of their emplcyees, makes any warranty, express or implied, or assumes any legal liability or responsibility for the accuracy, completeness, or usefulness of any information, apparatus, product, or process disclosed, or represents that its use would not infringe privately owned rights. Reference herein to any specific commercial product, process, or service by trade name, trademark, manufacturer, or otherwise does not necessarily constitute or imply its endorsement, recommendation, or favoring by the United States Government or any agency thereof. The views and opinions of authors expressed herein do not necessarily state or reflect those of the United States Government or any agency thereor. 


\section{DISCLAMMER}

Portions of this document may be illegible in electronic image products. Images are produced from the best available original document. 


\title{
EVALUATION OF STANDARD DURABILITY TESTS TOWARDS THE QUALIFICATION PROCESS FOR THE GLASS-ZEOLITE CERAMIC WASTE FORM
}

\author{
L. J. SIMPSON and D. J. WRONKIEWICZ \\ Argonne National Laboratory, 9700 South Cass Avenue, Argonne, IL 60439
}

ABSTRACT

Glass-bonded zeolite is being developed as a potential ceramic waste form for the disposition of radionuclides associated with the U.S. Department of Energy's (DOE's) spent nuclear fuel conditioning activities. The utility of several standard durability tests [e.g., Materials Characterization Center Test \#1 (MCC-1), Product Consistency Test-B (PCT-B), and Vapor Hydration Test (VHT)] was evaluated as a first step in developing methods and criteria that can be applied towards the process of qualifying this material for acceptance into the DOE Civilian Radioactive Waste Management System. The effects of $\mathrm{pH}$, leachant composition, and sample surface-area-to-leachant-volume ratios on the durability test results are discussed, in an attempt to investigate the release mechanisms and other physical and chemical parameters that are important for the acceptance criteria, including the establishment of appropriate test methodologies required for product consistency measurements.

Results from PCT-Bs conducted with $4 \mu \mathrm{m}$ diameter salt-loaded zeolite powder indicate that a good correlation exists between release rate and ionic size and/or charge for the release behavior of the simulated fission products in deionized water (DIW), EJ-13 groundwater, and brine solutions. Simulated divalent and trivalent fission products [ $\mathrm{Sr}, \mathrm{Ba}$, and rare earth (RE) ions] were preferentially retained in the zeolite (relative to the singly ionized cations) after tests with the salt-loaded zeolite in DIW. In general, the preferential cation release order for salt-loaded zeolite $\mathrm{A}$ in DIW is $\mathrm{Li}>\mathrm{Na} \geq \mathrm{K}>\mathrm{Cs}>\mathrm{Al}>\mathrm{Si}>\mathrm{RE}>\mathrm{Sr}>\mathrm{Ba}$. Results from PCT-Bs with the salt-loaded zeolite A immersed in high-ionic-strength brines at $90^{\circ} \mathrm{C}$ indicate a significant increase, relative to DIW tests, in the release rates of the $\mathrm{Sr}, \mathrm{Ba}$, and $\mathrm{RE}$ ions despite a decrease in the release of the $\mathrm{Si}$ and $\mathrm{Al}$ ions that make up the framework matrix of the zeolite. An increase in the $\mathrm{Mg}$ and $\mathrm{Ca}$ concentrations in the reacted zeolites suggests that an ion exchange process may be responsible for this increase.

Vapor hydration and MCC-1 tests were performed with ceramic waste form monoliths of glass-bonded zeolite. The VHTs (temperatures at 120,150 , and $200^{\circ} \mathrm{C}$ ) provided useful information about the effect of glass composition on corrosion rates and alteration phase formation, and about the overall toughness and structural integrity of the ceramic waste form. The MCC-1 test was investigated as an alternative to the PCT for acceptance criteria measurements. The MCC-1 results indicate that corrosion testing with both DIW and high-ionic-strength leachants (that specifically affect the ion exchange behavior of the fission products) are required to fully assess the durability of the ceramic waste form. These preliminary results establish the utility of the MCC-1 test for providing possible acceptance criteria measurements, including elemental release comparisons between the environmental assessment benchmark and the ceramic waste form.

\section{INTRODUCTION}

The electrometallurgical treatment program at Argonne National Laboratory is developing conditioning processes for the potential treatment of a diverse inventory of U.S. Department of Energy (DOE) spent nuclear fuel that may not be amenable for direct geologic disposal [1]. These include uranium metal, metal-Na bonded, and Three Mile Island core debris fuels. The electrometallurgical treatment program uses molten anhydrous $\mathrm{LiCl}-\mathrm{KCl}$ salt in the electrorefining process that accumulates approximately $10 \mathrm{wt} \%$ fission products $(\mathrm{Sr}, \mathrm{Cs}, \mathrm{Ba}, \mathrm{Ce}, \mathrm{La}, \mathrm{Nd}$, and $\mathrm{Y}$ ). This fuel conditioning generates two waste streams [1]: the residue from the electrorefiner anode and the salt. The anode residue is incorporated in a metal waste form, and fission products that accumulate in the salt are loaded into zeolites through a column ion-exchange process [1,2]. These zeolites, with high concentrations of fission products, are blended with additional zeolites to 
absorb any remaining free salt and are hot isostatically pressed with glass to produce a glassbonded zeolite, termed the "ceramic" waste form. Because the salt with the accumulated fission products is associated with the first stream in the processing of irradiated fuel and may contain transuranic elements, it is considered a high-level waste. This report focuses on the development and evaluation of tests for acceptance of the ceramic waste form.

The development of a technical basis for acceptance of a waste form into the DOE Civilian Radioactive Waste Management System must follow the guidelines presented in the Waste Acceptance System Requirements Document (WASRD, DOE/RW-0351, 1996) for spent nuclear fuel and high-level waste and in the Waste Acceptance Product Specifications (EM-WAPS, 1993) for borosilicate glass [3]. As outlined in the WAPS, the WASRD defines the "borosilicate glass" produced by programs directed from the DOE Office of Environmental Management as a standard high-level waste form. The WASRD specifications define the physical characteristics and consistency required for a waste form. These include chemical composition (elemental and oxide); crystalline phase projections; waste form production control demonstration through a comparison of the waste form with the environmental assessment benchmark (EA) glass (by a product consistency test); structural and compositional phase stability; and hazardous waste accountability.

To be accepted into the DOE Civilian Radioactive Waste Management System, the ceramic waste form must be reviewed and deemed "acceptable" with the identification and development of the appropriate qualification methods and criteria. As an initial step in this process, the present work evaluates the utility of standard durability tests for providing the information needed to qualify the ceramic waste form [3]. The Materials Characterization Center Test \#1 (MCC-1, "American Society for Testing and Materials" [ASTM] method C1220-92), Product Consistency Test (PCT) [4], and Vapor Hydration Test (VHT) [5] will be the focus of these initial investigations because of their widespread use in testing borosilicate glass, the ASTM approval of the PCT and MCC-1 test, and their use in qualification of borosilicate glass (e.g., PCT). A broad range of potential repository conditions were incorporated into the testing procedures to determine the bounding parameters appropriate for the corrosion testing of the ceramic waste form and its behavior under accelerated conditions. The effects of $\mathrm{pH}$, leachant composition, sample surfacearea-to-leachant-volume ratios, and test temperature on the results from durability tests with the ceramic waste form are discussed. Scanning electron microscopy with electron dispersive spectroscopy, analytical electron microscopy, and X-ray diffraction were used to provide background information about morphology, composition, structure, bonding, and alteration phase formation of both the ceramic waste form and the precursor material of zeolite, blended with simulated waste salt (salt-loaded zeolite).

\section{EXPERIMENTAL}

The ceramic waste form group of the electrometallurgical treatment program provided the samples used in these experiments. Equal amounts by weight of salt-loaded zeolite and glass were mixed together in an industrial mill, packed into 304 stainless steel canisters, and hot isostatically pressed to produce the ceramic waste form [7]. The zeolite and glass were uniformly distributed throughout the sample for dimensions greater than $100 \mu \mathrm{m}$. Compositional analyses from electron dispersive spectroscopy agreed reasonably well with the values calculated from the initial components of the zeolite and glass mixture (Table I). Electron beam stability of the zeolite during analytical electron microscopy indicated a low intrinsic water content in the ceramic waste form. To minimize pretest leaching, all sample cutting and polishing was performed without the use of any aqueous lubricants. Isopropyl alcohol was used to clean residual polishing material from the specimens. Except for the omission of aqueous lubricants, ASTM protocols were followed in the preparation of samples and in performing the durability tests [ASTM C1220-92, 4, 5].

Table I. Elemental compositions of the salt-loaded zeolite and ceramic waste form.

\begin{tabular}{|l|c|c|c|c|c|c|c|c|c|c|c|c|c|c|c|c|}
\hline Elements & $\mathrm{Li}$ & $\mathrm{B}$ & $\mathrm{Na}$ & $\mathrm{Al}$ & $\mathrm{Si}$ & $\mathrm{Cl}$ & $\mathrm{K}$ & $\mathrm{Ca}$ & $\mathrm{Y}$ & $\mathrm{Sr}$ & $\mathrm{Cs}$ & $\mathrm{Ba}$ & $\mathrm{La}$ & $\mathrm{Ce}$ & $\mathrm{Nd}$ & $\mathrm{O}$ \\
\hline SLZ, Wt\% & 1.36 & & 12.9 & 15.0 & 15.6 & 12.9 & 5.49 & & 0.01 & 0.06 & 0.63 & 0.21 & 0.13 & 0.24 & 0.39 & 35.1 \\
\hline CWF, Wt\% & 0.68 & 2.46 & 5.43 & 9.42 & 22.1 & 6.46 & 3.00 & 4.27 & 0.01 & 0.04 & 0.32 & 0.11 & 0.06 & 0.12 & 0.19 & 45.3 \\
\hline
\end{tabular}

SLZ: Salt-loaded zeolite 4A. CWF: Ceramic waste form. 
The evaluation of the durability tests was performed with both the precursor salt-loaded zeolite powders and ceramic waste form monoliths. Initial investigations focused on PCT-B procedures with the salt-loaded zeolite $4 \mathrm{~A}$ powder that has a mean grain diameter of approximately $4 \mu \mathrm{m}$. This work was performed to establish a baseline and investigate the mechanistic behavior of ion exchange and other elemental release properties of the salt-loaded zeolite. This information was required to determine the appropriate test procedures and to help interpret the durability test results with the ceramic waste form.

The evaluation of the VHT and MCC-1 durability tests was performed with monolithic ceramic waste form samples. The utility of these tests for providing useful information related to physical, chemical, and consistency issues of the acceptance criteria were investigated. This evaluation will require the incorporation of a range of potential repository fluid compositions into the PCT-B and MCC-1 test procedures to account for the possible effects of the repository groundwater and leachant variations on the ceramic waste form. The effect of brines on the ceramic waste form may be important when considering disposition in an unsaturated repository where fluids that condense on the waste form surface react with the glass in the sample, creating a concentrated leachate (brine). The composition of such a fluid, with a high solid/liquid ratio, will be controlled by the composition of the solid waste form.

Coupons for the VHTs and MCC-1 tests were "dry" cut from the ceramic waste form samples with a diamond saw. The sample surfaces were polished to 240 grit for the MCC-1 tests and 600 grit for the VHTs (without the use of any lubricant), sonicated for five minutes in isopropyl alcohol to remove any polishing residue, and dried in a $90^{\circ} \mathrm{C}$ oven for ten minutes. The VHT samples were suspended by a Teflon thread in a stainless steel canister, and placed in high temperature ovens (at 120,150 , and $200^{\circ} \mathrm{C}$ ). Enough DIW was added to the test vessel to provide $100 \%$ relative humidity inside the test chamber, but the amount was limited to prevent dripping of accumulated fluid from the samples. This keeps all the dissolution products in contact with the sample surface in a thin film of water, where they precipitate to form alteration phases.

\section{RESULTS AND DISCUSSION}

\section{Product Consistency Test-B (PCT-B) with Salt-Loaded Zeolite 4A}

In evaluating results from the different durability tests, the relatively small size and interconnected channels of the zeolite framework may be extremely important. Therefore, a detailed understanding of the ion exchange behavior of the salt-loaded zeolite is required. The effects of several leachant compositions on the PCT-B with $4 \mu \mathrm{m}$ diameter salt-loaded zeolite $4 \mathrm{~A}$ powders have been examined. The leachants included deionized water (DIW), equilibrated Yucca Mountain groundwater (EJ-13) [12], Ca-Na-K-Cl brine, $\mathrm{Mg}-\mathrm{Na}-\mathrm{K}-\mathrm{Cl}$ brine [ASTM C1220-92], and phosphate buffers at different $\mathrm{pH}$ values. The incorporation of these fluids, that represent a broad range of leachants to which the waste form may be exposed, into durability test procedures should provide information about the bounding parameters and mechanistic release scenarios appropriate for the corrosion testing of the ceramic waste form and about the behavior of the waste form under accelerated testing conditions.

The PCT-Bs were initiated with the salt-loaded zeolite in DIW to investigate the time dependent release, size-fraction release, and solubility of specific components. Tests were performed on samples that were held at $90^{\circ} \mathrm{C}$; for 2 minutes, 1 hour, 3, 7, 28, and 91 days; with a geometric surface area to leachant volume ratio $(\mathrm{S} / \mathrm{V})$ of $2000 \mathrm{~m}^{-1}$ (Figure 1). Each test used individual material and upon termination the solids and leachates were separated and analyzed. Results from $S / V=2000 \mathrm{~m}^{-1}$ and $20,000 \mathrm{~m}^{-1}$ PCT-Bs with the salt-loaded zeolite 4A in EJ-13, and ASTM Ca-Na-K-Cl and $\mathrm{Mg}-\mathrm{Na}-\mathrm{K}-\mathrm{Cl}$ brines at $90^{\circ} \mathrm{C}$ for 7,28 , and 91 days were also obtained. Additional $S / V=20,000 \mathrm{~m}^{-1}$ tests in DIW were also performed at $90^{\circ} \mathrm{C}$ for $3,7,28$, and 91 days.

To better represent the possible ion exchange or preferential ion release processes that may be occurring (where the external geometric surface area is less important and the correlation between the amount released and the total amount of an element in the sample may be more useful) the PCT-B leachate results are reported in fractional release percent $\left[\mathrm{FR}_{i} \%=100 \bullet\right.$ (mass of $i$ th element released)/(total mass of the $i$ th element in the sample)]. However, geometric effects are 
important and must be considered for any meaningful evaluation. The $\mathrm{FR}_{\mathrm{i}} \%$ results of these PCT-B experiments indicate that:

1. $20 \%$ of the $\mathrm{Li}$ and $\mathrm{Cl}$ was released within an hour of contact with DIW.

2. $60+\%$ of the $\mathrm{Li}$ was released within 3 days with all leachants (Figures 1, 2, and 3).

3. $\mathrm{Na}$ and $\mathrm{K}$ release occurred at a slower rate, with $20+\%$ released after 3 days (all leachants except brines).

4. $10 \%$ of the zeolite Al-Si framework was also released after 3 days in DIW at $2000 \mathrm{~m}^{-1}$.

5. An inverse correlation may exist between $\mathrm{FR}_{\mathrm{i}} \%$ and ionic radius and/or charge in DIW (Table II).

6. The release rates decreased substantially after 7 days in all leachants.

7. The preferential cation release order at $90^{\circ} \mathrm{C}$ in all the leachants except the brines is $\mathrm{Li}>\mathrm{Na} \geq \mathrm{K}>\mathrm{Cs}>\mathrm{Al}>\mathrm{Si}>\mathrm{RE}>\mathrm{Sr}>\mathrm{Ba}$ ( $\mathrm{RE}=$ rare earth).

8. Preferential ion exchange occurred between $\mathrm{Ca}$ and $\mathrm{Mg}$ species from solution and the $\mathrm{Na}$ and $\mathrm{K}$ in the zeolite.

9. Substantial increases in $\mathrm{RE}, \mathrm{Sr}$, and $\mathrm{Ba}$ release were observed in the brines at $90^{\circ} \mathrm{C}$, relative to the tests in DIW and EJ-13 leachant (Figures 1 and 2).

10. The $\mathrm{RE}$ elements released in the $\mathrm{Ca}$ brine leachate formed a $\mathrm{RE}-\mathrm{Ca}-\mathrm{Si}-\mathrm{Cl}$ precipitate. The salt-loaded zeolite powders used in these PCT-Bs have extremely high surface areas that are not representative of the actual material to be disposed and the results are not directly comparable with standardized PCTs conducted with materials having grain sizes between 75 and $150 \mu \mathrm{m}[6]$. However, the results from these PCT-Bs do provide information about the relative release rates and mechanisms of the different salt-loaded zeolite components. Table II lists the specific FR $\%$ data for leachate ions as a function of ionic charge and radius (7-day PCT-Bs in DIW at $90^{\circ} \mathrm{C}$ with $\mathrm{S} / \mathrm{V}=2000$ and $20,000 \mathrm{~m}^{-1}$ ). Elemental release results from these tests are consistent with previously published $\mathrm{S} / \mathrm{V}=7500 \mathrm{~m}^{-1}$ results (Table II) [6], demonstrating a possible correlation between release rate and ionic size and charge of the salt-loaded zeolite constituents, along with possible solubility effects associated with the $\mathrm{FR}_{\mathrm{i}} \%$ decrease of some of the elements with increasing $\mathrm{S} / \mathrm{V}$.

In most of the tests, the $\mathrm{pH}$ of the system is allowed to change in accordance with the reactions taking place. However, to investigate the effect of $\mathrm{pH}$ on the durability tests, buffered leachates with defined $\mathrm{pH}$ were used. The $\mathrm{S} / \mathrm{V}=2000 \mathrm{~m}^{-1} \mathrm{FR}_{\mathrm{i}} \%$ results of PCT-Bs with saltloaded zeolite $4 \mathrm{~A}$ in phosphate $\mathrm{pH}$ buffered leachants at $90^{\circ} \mathrm{C}$ for 3 days (Figure 3 ) indicate that the $\mathrm{Si}$ release rate was $\mathrm{pH}$ dependent. The $\mathrm{FR}_{\mathrm{i}} \%$ of $\mathrm{Si}$ increased from 3 to $40 \%$ between $\mathrm{pH}=9.5$ and 3 , respectively. Correspondingly, the $\mathrm{Ba}, \mathrm{Sr}$, and $\mathrm{RE} \mathrm{FR} \%$ also increased significantly from $\mathrm{pH}=9.5$ to $\mathrm{pH}=3$. The $\mathrm{Ba}, \mathrm{Sr}$, and $\mathrm{RE}$ ions released from the sample passed through a $0.45 \mu \mathrm{m}$ filters but not through a $0.02 \mu \mathrm{m}$ filters, suggesting that colloids were forming. Phosphate was found in the zeolite after the tests (as much as $5 \mathrm{wt} \%$ at $\mathrm{pH}=3$ ), suggesting that phosphate is not an appropriate buffer for this system. The release rates of the singly charged ions $(\mathrm{Li}, \mathrm{Na}, \mathrm{K}, \mathrm{Cl}$, and $\mathrm{Cs}$ ) were not affected by $\mathrm{pH}$. This result may be due to preferential ion release processes dominating the loss mechanism of these ions.

The above findings indicate that leachant composition, including $\mathrm{pH}$, may significantly affect the evaluation of the results from the durability tests performed on the ceramic waste form. The disproportionately high release of the alkali metals and chloride from the salt-loaded zeolites in the PCT-Bs indicates that preferential ion release (as opposed to bulk dissolution of the entire material) is the primary loss mechanism. Furthermore, the increased release of $\mathrm{Ba}, \mathrm{Sr}$, and $\mathrm{RE}$ ions in the presence of high-ionic-strength fluids may be important should brine-like fluids contact the waste form in the repository.

\section{MCC-1 Tests with the Ceramic Waste Form}

The 3-, 7-, and 28-day MCC-1 tests were performed with the ceramic waste form in DIW, EJ-13, and ASTM Mg-Na-K-Cl brine leachants. Scanning electron microscopy images of the monolith surfaces from the 28-day MCC-1 tests indicate that corrosion pitting increased significantly in the zeolite regions for tests in DIW, compared to tests in EJ-13 or Mg-Na-K-Cl brine leachants. The leachate analyses indicated that the $\mathrm{Ba}, \mathrm{Sr}$, and $\mathrm{RE}$ ions had very low release 
rates (at or below detection limits) in DIW and EJ-13 leachants. However, the release of these ions increased substantially in the $\mathrm{Mg}-\mathrm{Na}-\mathrm{K}-\mathrm{Cl}$ brine. As evident from the results of the PCT-Bs with the zeolite powders, this increase has been associated with enhanced ion exchange between the zeolite and the high-ionic-strength leachant. These trends suggest that the zeolite in the ceramic waste form should preferentially retain nearly all the contained divalent and trivalent fission products, except in the presence of a brine, where retention of these ions may be more dependent on the leach resistance of the glass matrix.

One of the WAPS criteria for borosilicate glass is a comparison between the release of $\mathrm{Li}$, $\mathrm{Na}$, and boron from the test glass and from the environmental assessment (EA) glass. While the WAPS protocol established the PCT procedure for the comparison, the use of the $S / V=10 \mathrm{~m}^{-1}$ MCC-1 test was investigated in these tests as a possible alternative procedure. The 28-day MCC-1 normalized elemental mass loss $\left(\mathrm{NL}_{\mathrm{i}}\right.$, eq. 1) results obtained for the ceramic waste form compare favorably with similar results for the EA glass [9] and a Savannah River Laboratory (SRL) composite glass [10] (Table III and IV). The SRL composite glass was chosen for comparison here because it is similar in composition to the EA glass, it contains Cs (an element not found in the EA glass), and results for brine leachants are reported. Since boron is a highly soluble component in the presence of alteration products, it is often used as an indicator of the glass matrix reaction with the leachate. For the ceramic waste form, boron is present only in the glass and thus is ideally suited to monitor the dissolution of the glass matrix. Similarly, Li is contained only in the zeolite and should provide a useful maximum measure of the alkali metal release. Cesium is contained only in the salt-loaded zeolite and the PCT-Bs with the salt-loaded zeolites indicated that Cs has the greatest release in DIW of all the simulated fission products and should provide a reasonable measure for monitoring maximum radionuclide release via ion exchange with the zeolite crystals. The results listed in Table III indicate that the $\mathrm{NL}_{\mathrm{i}}$ of $\mathrm{Cs}, \mathrm{Si}, \mathrm{Li}, \mathrm{Na}$, and boron from the ceramic waste form are lower than either the EA or the SRL composite glass when reacted in DIW. Similarly, the Cs, $\mathrm{Si}$, and boron release for the ceramic waste form are equivalent to the SRL composite glass in brine solutions (Table IV).

$$
N L_{i}=\frac{C_{i} V_{s}}{f_{i} A}\left(g / m^{2}\right)
$$

where $C_{i}$ is the concentration of $i$ th element released to solution, $V_{s}$ is the volume of leachate, $f_{i}$ is the fraction of the $i$ th element in the sample, and $\mathrm{A}$ is the surface area of the sample. The $\mathrm{NL}_{\mathrm{i}}$ is usually associated with the dissolution of the material (primarily a surface effect) and accounts for the external geometric surface area involved.

\section{Vapor Hydration Tests with the Ceramic Waste Form}

After termination of several of the tests at set time intervals, examination of the coupons indicated that the VHT samples were significantly affected by differences in structural integrity. Analysis of scanning electron microscopy images of the cross sections of the coupons indicates that severe fracturing occurred (Figure 4a), with more and longer fractures developing in:

(1) samples where the zeolite had converted to microsommite $\left[(\mathrm{Ca}, \mathrm{Na}, \mathrm{K})_{8}(\mathrm{Al}, \mathrm{Si})_{12} \mathrm{O}_{24} \mathrm{Cl}_{2.5}\right]$ during the hot isostatic pressing, (2) samples tested for longer times, and (3) samples tested at higher temperatures. Sodium chloride crystals (cubic or dendritic growth features in Figure $4 \mathrm{~b}$ ), $\mathrm{KCl}$ crystals, Ca-Al-Si spherical phases (small round bright spots in Figure 4b), and Na-Al-Si-RE "stick" phases (bright "stick" features in Figure 4b) were observed on the surface of the samples after the VHTs. Higher temperatures resulted in an increase in the amount of precipitates observed on the surface. Patches of RE phases were present before and after the VHTs, and were associated with high concentrations of chlorides. 


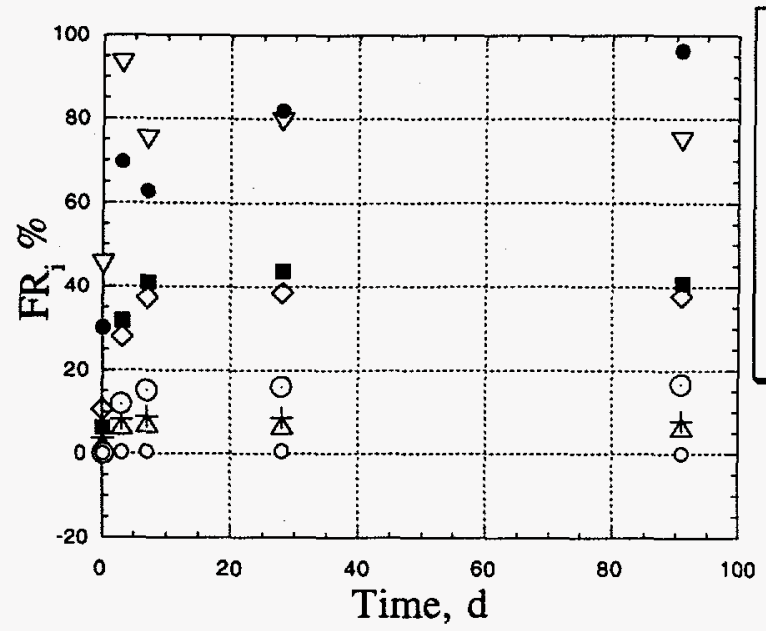

Figure 1. Fractional release of elements from $2000 \mathrm{~m}^{-1}$ PCT-Bs with salt-loaded zeolite 4A in DIW at $90^{\circ} \mathrm{C}$ (leachant $\mathrm{pH}=10$ after 91 days).

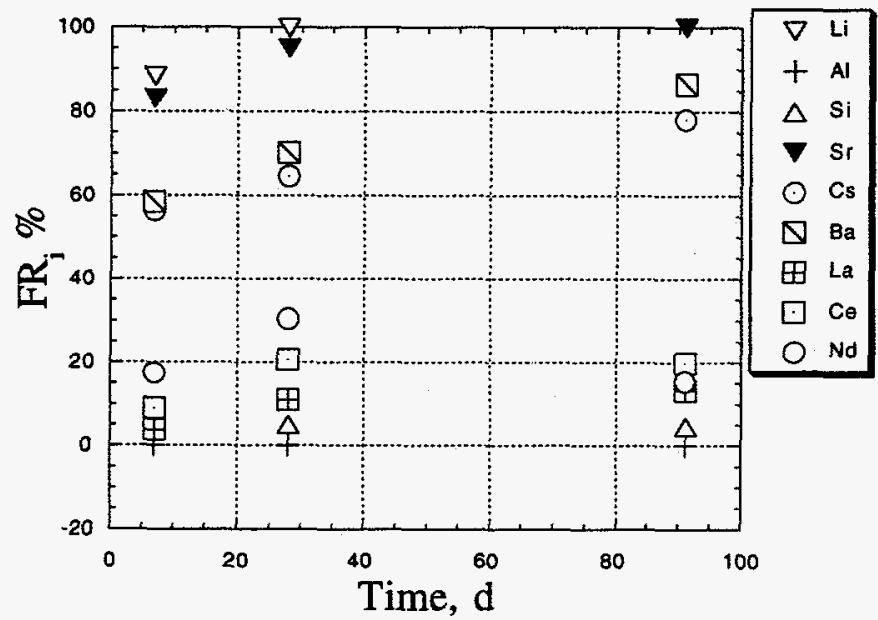

Figure 2. Fractional release of elements from $2000 \mathrm{~m}^{-1}$ PCT-Bs with zeolite 4A in Mg-Na-K-Cl Brine at $90^{\circ} \mathrm{C}$ (leachant $\mathrm{pH}=5.6$ after 91 days).
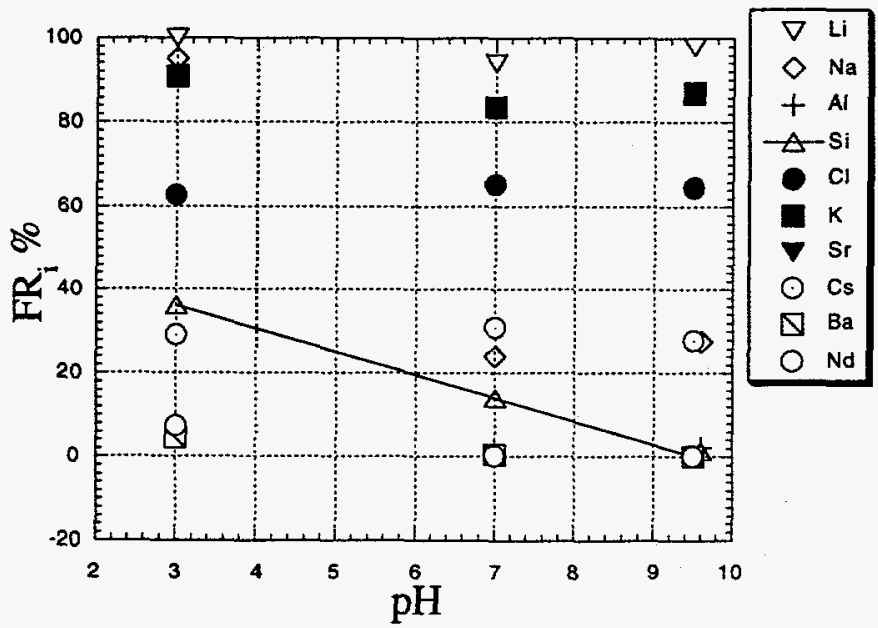

Figure 3. Fractional release of elements from $2000 \mathrm{~m}^{-1}$ PCT-Bs with salt-loaded zeolite $4 \mathrm{~A}$ in phosphate buffer solutions at $90^{\circ} \mathrm{C}$.
Table II. Comparison of $\mathrm{FR}_{\mathrm{i}} \%$ in 7 day PCT-B data with ionic charge and radii.

\begin{tabular}{|l|l|l|l|l|}
\hline Ions & $\begin{array}{l}\text { Ionic } \\
\text { Radius } \\
(\mathrm{nm})\end{array}$ & $\begin{array}{l}7 \mathrm{~d} \\
\mathrm{FR}_{\mathrm{i}} \% \\
2,000 \\
\mathrm{~m}^{-1}\end{array}$ & $\begin{array}{l}{ }^{[6]} 7 \mathrm{~d} \\
\mathrm{FR}_{\mathrm{i}} \% \\
7,500 \\
\mathrm{~m}^{-1}\end{array}$ & $\begin{array}{l}7 \mathrm{~d} \\
\mathrm{FR}_{\mathrm{i}} \% \\
20,000 \\
\mathrm{~m}^{-1}\end{array}$ \\
\hline $\mathrm{Li}^{+}$ & 0.060 & 75 & 68 & 79 \\
\hline $\mathrm{Na}^{+}$ & 0.095 & 39 & 26 & 35 \\
\hline $\mathrm{K}^{+}$ & 0.133 & 39 & 25 & 34 \\
\hline $\mathrm{Cs}^{+}$ & 0.169 & 15 & 2.8 & 10 \\
\hline $\mathrm{Sr}^{2+}$ & 0.113 & 0.05 & & $<0.01$ \\
\hline $\mathrm{Ba}^{2+}$ & 0.135 & $<0.01$ & & $<0.01$ \\
\hline $\mathrm{Nd}^{3+}$ & 0.108 & 0.5 & & $<0.01$ \\
\hline $\mathrm{Ce}^{3+}$ & 0.111 & 0.4 & & $<0.01$ \\
\hline $\mathrm{La}^{3+}$ & 0.115 & 0.16 & & $<0.01$ \\
\hline $\mathrm{Al}^{3+}$ & 0.050 & 8.9 & 5.3 & 1.2 \\
\hline $\mathrm{Si}^{4+}$ & 0.041 & 7.3 & 4.7 & 0.34 \\
\hline $\mathrm{Cl}^{+}$ & 0.181 & 65 & & 84 \\
\hline $\mathrm{pH}$ & & 10.2 & 10.9 & 10.9 \\
\hline
\end{tabular}

Table III. Comparison of 28 day $\mathrm{NL}_{\mathrm{i}}$ results $\left(\mathrm{g} / \mathrm{m}^{2}\right)$ from $90^{\circ} \mathrm{C}$ MCC- 1 tests in DIW.

\begin{tabular}{|l|l|l|r|}
\hline Element & $\begin{array}{l}\text { Ceramic } \\
\text { Waste } \\
\text { Form }\end{array}$
\end{tabular}

${ }^{*}$ Leachate $\mathrm{pH}=9$.

na - test data not available.

$\mathrm{np}$ - element is not present in material.

Table IV. Comparison of 28 day $\mathrm{NL}_{\mathrm{i}}$ results $\left(\mathrm{g} / \mathrm{m}^{2}\right)$ from $90^{\circ} \mathrm{C}$ MCC-1 tests in $\mathrm{Mg}-\mathrm{Na}-\mathrm{K}-\mathrm{Cl}$ Brines ( $\approx 25 \%$ total dissolved solids).

\begin{tabular}{|l|l|l|l|}
\hline Element & $\begin{array}{l}\text { Ceramic } \\
\text { Waste } \\
\text { Form }^{*}\end{array}$ & $\begin{array}{l}\text { Bench- } \\
\text { mark EA } \\
\text { Glass }^{[9]}\end{array}$ & $\begin{array}{l}\text { SRL Glass } \\
\text { Composite }^{[10]}\end{array}$ \\
\hline $\mathrm{B}$ & 8.7 & $\mathrm{na}$ & 8.7 \\
\hline $\mathrm{Si}$ & 7.6 & $\mathrm{na}$ & 5.9 \\
\hline $\mathrm{Cs}$ & 10.6 & $\mathrm{na}$ & 6.7 \\
\hline
\end{tabular}

"Leachate $\mathrm{pH}=5.5$.

na - test data not available. 


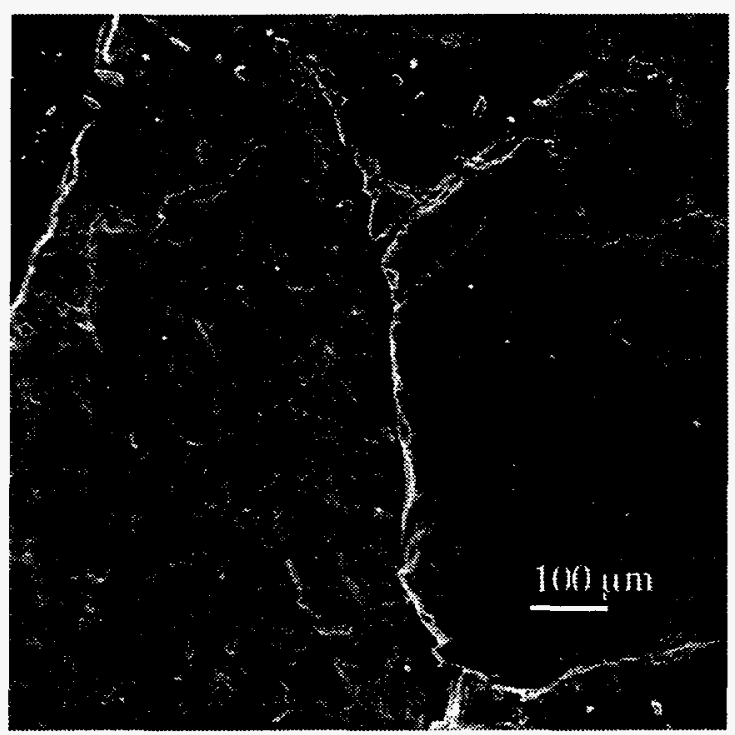

a

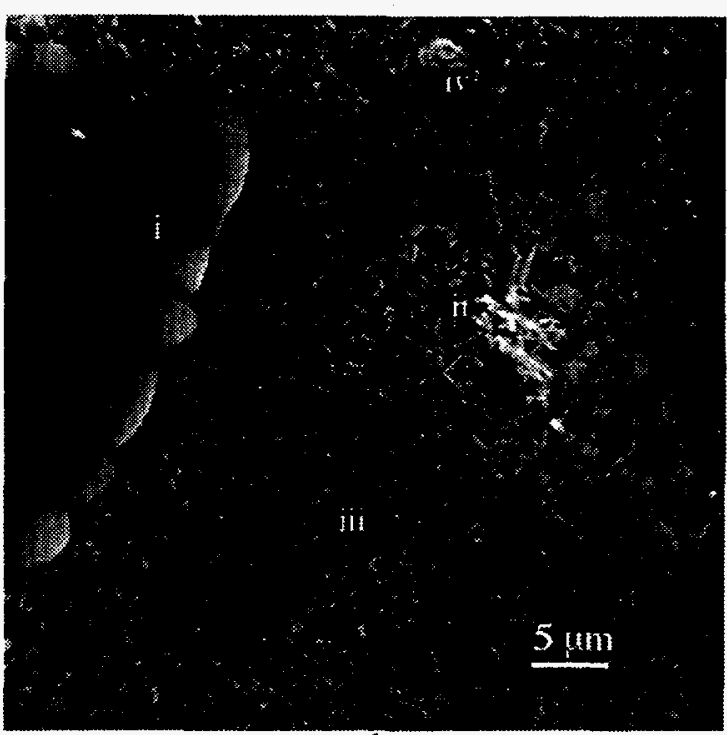

b

Figure 4. Secondary electron images from a scanning electron microscope. (a) Cross section of a ceramic waste form sample after a 3 day VHT at $200^{\circ} \mathrm{C}$, illustrating the significant amount of fracturing that occurred in these samples. A relatively limited amount of chemical alteration occurred at the surface of the sample (upper left corner). (b) Surface of a ceramic waste form sample after a 21 -day VHT at $200^{\circ} \mathrm{C}$. (i) The large feature on the left is a dendritic growth of $\mathrm{NaCl}$. (ii) The bright, stick-like feature (middle right) contains above average concentrations of RE ions. (iii) The small, gray, square features contain above average concentrations of $R E$ and chloride ions. (iv) A small $\mathrm{Ca}-\mathrm{Al}-\mathrm{Si}$ rich spherical feature (middle top) is also present. Pores due to corrosion are present throughout.

According to preliminary measurements, the rate at which the surface alteration layer forms in these initial VHTs with ceramic waste from monoliths is similar to that for the SRL202 glass [11] reacted under identical conditions. However, quantitative measurement of alteration layer formation was very difficult because of the excessive fracturing of the samples. The VHT provided information about the toughness and structural integrity of the ceramic waste form, but the qualitative nature of layer thickness measurements limits the usefulness of VHT corrosion rates for qualification studies. The VHT can provide information about the ceramic waste form alteration phases that may be useful for the performance assessment modeling efforts required for geologic disposal.

\section{CONCLUSIONS}

The utility of the VHT and MCC-1 tests for elucidating the criteria for acceptance of the ceramic waste form into the DOE Civilian Radioactive Waste Management System was investigated. The preliminary results indicate that the MCC-1 test can provide the relevant information required for acceptance of the ceramic waste form with regards to consistency. Additional PCT-B investigations with salt-loaded zeolite $4 \mathrm{~A}$ powders were performed to determine the release mechanisms and the effect of leachants on the zeolite. The use of DIW as a leachant provides the upper bound for the corrosion of the ceramic waste form where the system $\mathrm{pH}$ is neutral or basic. Acidic $\mathrm{pH}$ leachants increased the dissolution of the zeolite framework matrix. The use of high-ionic-strength brines increased the release of the alkaline earth and RE elements from the salt-loaded zeolite, and $\mathrm{Ca}, \mathrm{Mg}$, and $\mathrm{P}$ were preferentially ion exchanged for the zeolite cations $\mathrm{Na}$ and $\mathrm{K}$. These results indicate that both $\mathrm{DIW}$, which affects the dissolution of the zeolite framework, and leachants, which specifically affect the ion exchange behavior of the fission products, are required to fully assess the durability of the ceramic waste form. Furthermore, to avoid premature dissolution of alkali metal and chloride ions, the use of water should be limited in any of the sample preparation steps. 
As observed in the PCT-Bs with the salt-loaded zeolite, preferential ion release was the dominant loss mechanism. The univalent ions are preferentially released over the divalent and trivalent ions in DIW and EJ-13 leachant. The order of cation release from the salt-loaded zeolites is affected by the leachant solubility of specific ions. Thus, the addition of specific ions to the leachant may have dramatic effects on the ion exchange properties of the zeolite. This was most evident with the salt-loaded zeolite and ceramic waste form samples in the $\mathrm{Mg}$ and $\mathrm{Ca}$ brines. In general, $\mathrm{Sr}, \mathrm{Ba}$, and the RE ions have very low release rates from the zeolites in DIW and lowionic-strength leachants. However, the high-ionic-strength brines change the equilibrium conditions of the zeolites such that the release of the alkaline earth and the RE ions was dramatically increased (Figure 2), and $\mathrm{Mg}$ and $\mathrm{Ca}$ were preferentially ion exchanged with the $\mathrm{Na}$ and $\mathrm{K}$ in the zeolites. Furthermore, $\mathrm{Ca}$ and perhaps $\mathrm{Mg}$ form precipitates with the $\mathrm{RE}$ ions.

The effect of sample glass composition on corrosion rates and alteration phase formation was investigated with VHTs between 120 and $200^{\circ} \mathrm{C}$. The VHT provided information about the toughness and structural integrity of the ceramic waste form. However, the qualitative nature of layer thickness measurements limits the usefulness of the VHT corrosion rates for qualification studies. The VHT can provide information about the long-term alteration phases of the ceramic waste form that may be useful for the performance assessment efforts required for geologic disposal. Presently, the formation of stress induced fractures in the hot isostatically pressed samples adversely affects the evaluation of the VHT and may exacerbate the analysis of the MCC-1 tests if fracturing significantly changes the exposed surface areas of these samples during the course of the tests. Fracturing may also affect the results from PCT and other test protocols that are presently being evaluated for use in determining acceptance criteria.

\section{ACKNOWLEDGMENTS}

This work was supported by the U.S. Department of Energy, Nuclear Energy Research and Development Program, under Contract No. W-31-109-Eng-38. The insightful and extremely relevant comments from the reviews of this paper by J. K. Bates and D. M. Strachan are greatly appreciated.

\section{REFERENCES}

1. C. C. McPheeters, J. P. Ackerman, G. K. Johnson, 1st Seminar on Molten Salts in Nuclear Technologies, Dimitrovgrad, Russia, June 19-23, 1995.

2. A. Dyer, An Introduction to Zeolite Molecular Sieves (John Wiley and Sons, NY, 1988).

3. U.S. Department of Energy, Office of Civilian Radiactive Waste Management, Waste Acceptance System Requirements Document, Report No. DOE/RW-0351, Rev. 2, 1996.

4. C. M. Jantzen, N. E. Bibler, D. C. Beam, W. G. Ramsey, and B. J. Waters, Westinghouse Savannah River Co. Report No. WSRC-TC-90-539, Rev. 2 (1992).

5. J. K. Bates, M. G. Seitz, and M. J. Steindler, Nucl. Waste Chem. Mgmt. 5, 63 (1984).

6. M. A. Lewis, D. F. Fischer, and L. J. Smith, J. Am. Ceram. Soc. 76 (11), 2826 (1993).

7. M. A. Lewis, D. F. Fischer, and C. D. Murphy, Ceramic Trans. 45, 277 (1994).

8. J. W. Sade and G. D. Piepel, Report No. WSRC-TR-90-526, Westinghouse Savannah River Co., Aiken, SC, 1991.

9. P. R. Hrma, G. F. Piepel, M. J. Schweiger, D. E. Smith, D. S. Kim, P. E. Redgate, J. D. Vienna, C. A. LoPresti, D. B. Simpson, D. K. Peeler, and M. H. Langowski, Pacific Northwest Laboratory Report No. 10359, Vol. 2, 1994.

10. M. J. Plodinec, G. G. Wicks, and N. E. Bibler, Savannah River Laboratory Report No. DP-1629 (1982).

11. D. J. Wronkiewicz, L. M. Wang, J. K. Bates, and B. S. Tani, Mat. Res. Soc. Symp. Proc. Vol. 294, 183 (1993).

12. W. L. Ebert, J. K. Bates, and E. C. Buck, Mat. Res. Soc. Symp. Proc. Vol. 294, 137 (1993). 